IRA-International Journal of Management \& Social Sciences

ISSN 2455-2267; Vol.06, Issue 02 (2017)

Pg. no. 130-137

Institute of Research Advances

http://research-advances.org/index.php/RAJMSS

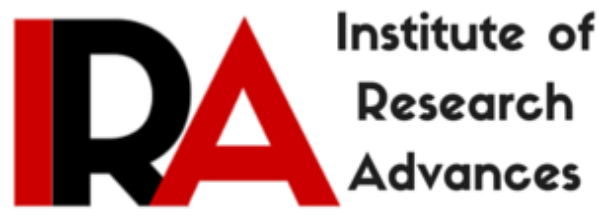

\title{
Disclosure Practices in Selected Private Sector Companies in India
}

Dr. Ashish Mittal (M.com, MBA, Phd)

Manager (Finance \& Accounts),

Ambika Food Products at Saharanpur ( U.P.), India.

Type of Review: Peer Reviewed.

DOI: http://dx.doi.org/10.21013/jmss.v6.n2.p1

\section{How to cite this paper:}

Mittal, A. (2017). Disclosure Practices in Selected Private Sector Companies in India. IRAInternational Journal of Management \& Social Sciences (ISSN 2455-2267), 6(2), 130-137. doi:http://dx.doi.org/10.21013/jmss.v6.n2.p1

(C) Institute of Research Advances

(cc) EY-NG

This work is licensed under a Creative Commons Attribution-Non Commercial 4.0 International License subject to proper citation to the publication source of the work.

Disclaimer: The scholarly papers as reviewed and published by the Institute of Research Advances (IRA) are the views and opinions of their respective authors and are not the views or opinions of the IRA. The IRA disclaims of any harm or loss caused due to the published content to any party. 


\begin{abstract}
Corporate Disclosure can be defined as a process through which a business enterprise communicates with the external parties. Disclosure is the movement of information from the private domain (inside information) into the public domain. To evaluate the disclosure level of various companies, some yardstick is required. A comprehensive list of 14 major items with breakup of 482 sub items has been made to determine the adequacy of disclosure practices of the corporate sector in India. Disclosure practices in selected 16 public sector companies at two points of time i.e. 1990-91 and 2006-07 has been divided into two sections i.e. Company wise analysis of Disclosure Score and Analysis of Major items of information. On the basis of Company wise analysis of Disclosure Score and Analysis of Major items of information, it can be concluded that there is considerable improvement in the various items disclosed by Private Sector companies over the period of study.
\end{abstract}

\title{
INTRODUCTION
}

Corporate Disclosure can be defined as a process through which a business enterprise communicates with the external parties. ${ }^{1}$ Disclosure is the movement of information from the private domain (i.e. inside information) into the public domain. ${ }^{2}$ The corporate reports are disclosed through company's annual reports: Annual report is a periodic statement, which is issued at the end of each accounting period. ${ }^{3}$ It usually consists of accounting and non accounting information. Accounting information are quantitative, formal, structural, numerical and past oriented materials. This includes Balance Sheet, Profit and Loss accounts, Schedules and notes to financial statements. These are generally audited be a qualified auditor. They must exhibit "true and fair view" of the state of affairs. Corporate disclosure is a process of reporting of accounting information of an entity to a user or a group of users. It signifies a total communication system between the corporation and its interested constituents. This is the most direct, least expensive, most timely and fairest methods of reaching present and potential users. So, corporate reporting is nothing but the communication of financial information of the activities of the undertaking to the interested parties for facilitating their economic decisions. ${ }^{4}$ Generally, three concepts have been proposed for disclosure and they are adequacy, fairness and full disclosure. The most commonly used concept is adequacy; and it implies that all material information needed by the users of the financial statements are reports should be included in such financial statements and reports i.e. it should be adequate to the need of the users. The adequacy of the information can be tested when it is reported outside the organization, but when reported inside the organization, the adequacy of the disclosure cannot be tested accurately as there is no test to measure it. Another difficulty is that the needs of the users are different from user to user, and as a result, adequacy can be obtained only to a certain extent. The concept of 'fair disclosure' implies that all users of the information should be treated alike, in preparing the financial statements and reports, and the concept of 'fair disclosure' implies that all users of the information should be treated alike, in preparing the financial statements and reports and the concept of 'full disclosure' implies that all relevant information of the financial activities of the business enterprise is presented in the financial reports. In the recent years, the perspective shifted to an informational approach. According to this approach, the basic purpose of financial statements is to provide information useful to various users, viz., investors, creditors, management, government, security analysts, consumers and the public. This shift in emphasis is fully reflected in the objectives of financial statements developed by the Financial Accounting Standard Board (FASB).

\footnotetext{
${ }^{1}$ Lal Jawahar Corporate Annual Report - Theory \& Practice, Starling Publisher Pvt. Ltd. New Delhi, 1985, P.38

${ }^{2}$ American Accounting Association, Conceptual Framework for financial accounting and reporting, Elements of Financial Statement and their measurement, AAA, June 1977, p.19.

${ }^{3}$ Himstreet, W.C. Brely, W.M. Business Communication, WM Publishing Co. Inc. California 1973, pp. 357380, (guidelines for writing the report effectively)

${ }^{1}$ Dr. M. Saeed, The Theory of Corporate Disclosure and its Applications in Financial Reporting, Anmol Publications New Delhi, p. 239
} 
Corporate disclosure or reporting signifies a total communication system between the corporation and its interested constituents. The parties interested in the business organization need financial information for making sound economic decisions. Information about a company's affairs can be communicated through different medias. The published annual report is the most widely used comprehensive source of corporate financial data. Full disclosure of information by a company assumes a great deal of significance for the interested parties. It helps them to take a variety of decisions. These reports can be meant for internal users, viz., management or external users viz., shareholders, debenture holders, financial institutions, security analysts, government, creditors, suppliers and general public. External reporting of information has assumed great significance over a period of time because of increase in the size of business units, scarcity of funds to finance the increased scale of operations, emergence of a large number of small investors, separation of ownership and management, increased public awareness, recognition by management of their responsibility towards various stakeholders and increased regulation of government forcing the companies to publicly make available essential business information. To evaluate the disclosure level of various companies, some yardstick is required. A list of disclosure index is being developed as yard stick on the basis of analysis of previous studies, literature, guidelines of ICAI for best presentation of accounts awards and a detailed consultation with various academicians, financial analysts etc. A comprehensive list of 14 major items with breakup of 482 sub items has been made to determine adequacy of disclosure practices of the corporate sector in India. A list comprising the major items and sub items of information is as under:

\begin{tabular}{|l|l|l|}
\hline S.No. & Major items of Classification & No. of Sub items \\
\hline 1. & Contents & 54 \\
\hline 2. & Directors Report & 59 \\
\hline 3. & Chairman's Report & 32 \\
\hline 4. & Corporate Governance & 26 \\
\hline 5. & MDA (Management Decision Analysis) & 26 \\
\hline 6. & Shareholder's Information & 51 \\
\hline 7. & Accounting and Finance & 96 \\
\hline 8. & Personnel/HR information & 27 \\
\hline 9. & Marketing and Segment Reporting & 20 \\
\hline 10. & Highlights & 25 \\
\hline 11. & Mission & 01 \\
\hline 12. & Graphs, Diagrams, Pictures & 44 \\
\hline 13. & Social responsibility & 11 \\
\hline 14. & Emerging Concepts & 10 \\
\hline & TOTAL & 482 \\
\hline
\end{tabular}

In India, corporate disclosure in case of public sector companies is governed by Companies Act, pronouncements of the Institute of Chartered Accountants of India (ICAI), guidelines of the Securities and Exchanges Board of India (SEBI) and the requirements of the Bureau of Public Sector Companies.

\section{DISCLOSURE PRACTICES IN SELECTED PRIVATE SECTOR COMPANIES}

Disclosure practices in selected public sector companies at two points of time i.e. 1990-91 and 2006-07 has been divided into two sections as under:-

1 Company wise analysis of Disclosure Score.

2 Analysis of Major items of information. 


\section{COMPANY WISE ANALYSIS OF DISCLOSURE SCORE.}

Table 1.1 shows the company-wise disclosure of the selected Indian companies of the private sector for the years 1990-91 and 2006-07. It also reveals the percentage increase/decrease in score in 2006-07 over 1990-91. Disclosure score for the companies has been computed by adding up the scores obtained by a company for all the items included in the index of disclosure. Analysis of disclosure of score of private sector companies clearly shows that the disclosure score of almost all the companies taken for study has improved in 2006-07 over 1990-91. Ambuja Cement Limited has shown remarkable improvement in the score from 78 items in 1990-91 to 248 items in 2006-01. It has registered improvement/increase of 217.95 percent in 2006-07 over 1990-91.

Table 1.1

COMPANY WISE DISCLOSURE SCORE IN SELECTED PRIVATE SECTOR COMPANIES

\begin{tabular}{|c|c|c|c|c|c|}
\hline \multirow[t]{2}{*}{$\begin{array}{l}\text { Sr. } \\
\text { No. }\end{array}$} & \multirow[t]{2}{*}{ Name of Company } & \multicolumn{2}{|c|}{$\begin{array}{l}\text { Disclosure } \\
\text { Score }\end{array}$} & \multirow{2}{*}{$\begin{array}{l}\text { Increase/ } \\
\text { Decrease in } \\
2007 \text { over } \\
1991\end{array}$} & \multirow{2}{*}{$\begin{array}{l}\text { Percentage } \\
\text { Increase } \\
\text { /Decrease in } \\
2007 \text { over } \\
1991\end{array}$} \\
\hline & & $\begin{array}{l}1990- \\
91\end{array}$ & $\begin{array}{l}2006- \\
07\end{array}$ & & \\
\hline 1 & $\mathrm{ACC}$ & 117 & 212 & 95 & 81.20 \\
\hline 2 & Indian Cements Ltd. & 107 & 191 & 84 & 78.50 \\
\hline 3 & Ambuja Cement Ltd. & 78 & 248 & 170 & 217.95 \\
\hline 4 & Narolac Paints & 94 & 165 & 71 & 75.53 \\
\hline 5 & Asian Paints & 152 & 241 & 89 & 58.55 \\
\hline 6 & Pfizer & 109 & 207 & 98 & 89.91 \\
\hline 7 & Morepan Ltd. & 69 & 180 & 111 & 160.87 \\
\hline 8 & Ranbaxy & 119 & 278 & 159 & 133.61 \\
\hline 9 & ITC Hotels & 87 & 147 & 60 & 68.97 \\
\hline 10 & Indian Hotels Ltd. & 127 & 205 & 78 & 61.42 \\
\hline 11 & Voltas & 134 & 228 & 94 & 70.15 \\
\hline 13 & Blue Star & 164 & 236 & 72 & 43.90 \\
\hline 13 & GKW Ltd. & 101 & 154 & 53 & 52.48 \\
\hline 14 & Ashok Leyland & 104 & 238 & 134 & 128.85 \\
\hline 15 & Apollo Tyres & 100 & 189 & 89 & 89.00 \\
\hline 16 & CEAT & 103 & 207 & 104 & 100.97 \\
\hline 17 & ITC & 144 & 232 & 88 & 61.11 \\
\hline 18 & Global Telesys Ltd. & 147 & 343 & 196 & 133.33 \\
\hline 19 & BILT & 137 & 256 & 119 & 86.86 \\
\hline 20 & INDAL & 156 & 285 & 129 & 82.69 \\
\hline 21 & HUL & 152 & 323 & 171 & 112.50 \\
\hline 22 & Siemens & 109 & 215 & 106 & 97.25 \\
\hline 23 & Tata Steel & 169 & 296 & 129 & 76.33 \\
\hline 24 & Grasim Industriess. Ltd & 98 & 212 & 114 & 116.33 \\
\hline
\end{tabular}

Source: Statistical values computed from Annual Reports of the Companies

Morepan Ltd. has minimum disclosure score of 69 in 1990-91. Its score has increased to 180 in 200607 i.e. improvement of 160.87 percent over 1990-91. Ranbaxy, Global Telesys Ltd., Ashok Leyland, Grasim, Hindustan Unilever Ltd., and CEAT have also shown improvements in their disclosure scores by 133.61 percent. 133.33 percent, 128.85 percent, 116.33 percent, 116.33 percent. 112.50 percent and 100.97 percent respectively. Analysis of table clearly exhibits that all the companies have shown an improvement in the score in 2006-07 over the year 1999-00. 
TABLE 1.2

CLASSIFICATION OF COMPANIES ON THE BASIS OF THEIR DISCLOSURE SCORES. (PRIVATE SECTOR)

\begin{tabular}{|c|c|c|c|c|}
\hline \multirow{2}{*}{ Disclosure Scores } & \multicolumn{2}{|c|}{$\mathbf{1 9 9 0 - 9 1}$} & \multicolumn{2}{c|}{ 2006-07 } \\
\cline { 2 - 5 } & No. of Co. & \%age & No. of Co. & \%age \\
\hline $0-50$ & 0 & 0 & 0 & 0 \\
\hline $50-100$ & 5 & 20.93 & 1 & 0 \\
\hline $100-150$ & 14 & 58.34 & 5 & 20.83 \\
\hline $150-200$ & 5 & 20.83 & 12 & 50.00 \\
\hline $200-250$ & 0 & 0 & 4 & 16.67 \\
\hline $250-300$ & 0 & 0 & 2 & 8.33 \\
\hline $300-350$ & 0 & 0 & 0 & 0 \\
\hline $350-400$ & 0 & 0 & 0 & 0 \\
\hline $400-450$ & 0 & 0 & $\mathbf{2 4}$ & $\mathbf{1 0 0}$ \\
\hline Total & $\mathbf{2 4}$ & $\mathbf{1 0 0}$ & & \\
\hline
\end{tabular}

Source: Statistical values computed from Annual Reports of the Companies

The table 1.2 exhibits the classification of the selected private sector companies on the basis of their disclosure score. The analysis of table reveals that 58.34 percent of companies have disclosure score ranging between 100-150 items in 1990-91. The percentage of companies disclosing in the range of 150200 is 20.83 percent in 1990-91 as well as in 2006-07. In 1990-91, none of the selected companies has disclosure score above the range of 150-200. Whereas, in 2006-07, 50 percent of the companies have disclosure of items in the range of 200-250. In the year 2006-07, the percentage of companies disclosing in the range of 250-300 and 300-350 is 16.67 percent and 8.83 percent receptively. None of the companies have disclosure score in the range of 350-400 and 400-430 during the period of study. Thus the analysis of results clearly shows that there is considerable improvement in the number and percentage of the companies showing higher disclosure score in 2006-07 over 1990-91.

Table 1.3

Comparison of Private Sector Companies on the Basis of Minimum and Maximum Disclosure Score

\begin{tabular}{|c|c|c|c|c|}
\hline \multirow{2}{*}{ Range } & \multicolumn{2}{|c|}{ 1990-91 } & \multicolumn{2}{c|}{ 2006-07 } \\
\cline { 2 - 5 } & Disclosure Score & Name of the Co. & Disclosure Score & Name of the Co. \\
\hline Minimum & 69 & Morepan & 147 & ITC Hotels \\
\hline Maximum & 169 & Tata Steel & 343 & GTS Ltd. \\
\hline
\end{tabular}

Source: Statistical values computed from Annual Reports of the Companies

Table 1.3 exhibits the minimum and maximum disclosure scores along with name of the companies for 1990-91 and 2006-07. The analysis of table shows an improvement in the minimum and minimum disclosure score of the private sector companies in 2006-07 over 1990-91. In 2006-07, the minimum disclosure score (147) is shown by ITC Hotels, and maximum disclosure score (343) has been shown by GTS Ltd. In 1990-91, minimum disclosure score (69) is shown by Morepan, and Tata Steel Ltd. has shown maximum disclosure score (169).

Table 1.4

Statistical Analysis of Score of Selected Private Sector Companies

\begin{tabular}{|l|c|c|}
\hline Statistics & $\mathbf{1 9 9 0 - 9 1}$ & $\mathbf{2 0 0 6 - 0 7}$ \\
\hline Mean & 119.88 & 228.67 \\
\hline Standard Deviation & 27.87 & 49.97 \\
\hline Coefficient of Variation & 23.25 & 21.85 \\
\hline ' $t$ '-value & \multicolumn{2}{|c|}{ ' $\mathrm{t}$ ' $=14.41^{*}$} \\
\hline
\end{tabular}

Source: Statistical values computed from Annual Reports of the Companies 
Note *: Significant at 0.05 level

Analysis of table 1.4 reveals the statistical values i.e. Mean, Standard Deviation and Coefficient of Variation score of the private sector companies in India for the years 1990-91 and 2006-07. There is a considerable improvement in the mean scores of the companies in 2014-15 over 1999-00. It has increased to 228.67 items from 119.88 items in 1999-00. Standard deviation has increased to 49.97 in 2014-15 from 27.87 in 1999-00. It is a signal of increase in absolute variability in scores over the period of the study. Coefficient of variation is being computed to measure the degree of variability in the scores. On the basis of analysis of Coefficient of variation it can be stated that Coefficient of variation has decreased to 21.85 in 2014-15 from 23.25 in 1999-00. The analysis of results indicate that ' $t$ ' value is significant at 0.05 level of significance. It means there is significant difference in the disclosure score of the private sector companies over the period of study.

\section{ANALYSIS OF MAJOR ITEMS OF INFORMATION}

This section deals with analysis of major items of information disclosed in annual reports by the corporate sector in India. After scanning the Annual Reports of the Companies, 14 major items of information have been identified. Table 1.5 exhibits the percentage of private sector companies disclosing major items of information. It also shows average number of disclosing companies (in \%age)

Table 1.5

Disclosure of Major items of Information by Private Sector Companies

\begin{tabular}{|l|l|c|c|c|}
\hline \multirow{2}{*}{$\begin{array}{l}\text { Sr. } \\
\text { No. }\end{array}$} & \multicolumn{1}{|c|}{ Items of Information } & \multicolumn{2}{c|}{$\begin{array}{c}\text { Percentage of Disclosing } \\
\text { companies }\end{array}$} & $\begin{array}{c}\text { Average } \\
\text { Disclosure } \\
\end{array}$ \\
\cline { 3 - 4 } & & $1999-2000$ & $\begin{array}{c}2014- \\
\text { Score (\%age) }\end{array}$ \\
\hline 1 & Contents & 75 & 92 & 83.50 \\
\hline 2 & Director's Report & 100 & 100 & 100.00 \\
\hline 3 & Chairman's Report & 29 & 42 & 35.50 \\
\hline 4 & Corporate Governance & 50 & 100 & 75.00 \\
\hline 5 & Mgt. Discussion \& Analysis & 58 & 100 & 79.00 \\
\hline 6 & Share holder's Information & 100 & 100 & 100.00 \\
\hline 7 & Information on Accountings \& Finance & 100 & 100 & 100.00 \\
\hline 8 & Information on Personnel & 100 & 100 & 100.00 \\
\hline 9 & Information on Marketing & 100 & 100 & 100.00 \\
\hline 10 & Highlights & 46 & 71 & 58.50 \\
\hline 11 & Mission \& Objectives & 29 & 29 & 29.00 \\
\hline 12 & Presentation by Graphs \& Pictures & 54 & 92 & 73.00 \\
\hline 13 & Social Responsibility & 67 & 83 & 75.00 \\
\hline 14 & Emerging Concepts & 25 & 25 & 25.00 \\
\hline
\end{tabular}

Source: Statistical values computed from Annual Reports of the Companies

The analysis of table shows that on an average the percentage of companies disclosing major items of information varies between 25-100 percent for the years 1999-00 as well as 2014-15. The analysis reveals that disclosure percentage by companies is 100 percent for the items of information on accounting and finance, (it includes Auditor's Report, Balance Sheet, Profit \& Loss Account, Schedules and notes etc.); Director's Report, Shareholders information, information on personnel and marketing. Analysis of table shows that on average 83.5 percent companies has disclosed contents in their annual reports. It guides the shareholders about the items disclosed along with its page number in the annual report. The percentage of companies disclosing contents has increased to 92 percent in 2014-15 from 75 percent in 1999-00. Management discussion and analysis has been disclosed on an average by 79 percent companies. There is considerable improvement in its disclosure from 58 percent in 1999-00 to 100 percent in 2014-15. 
Similarly, companies disclosing corporate governance have increased to 100 percent in 2014-15 over 50 percent in 1999-00.Disclosure of information on social responsibility has been given due importance by Companies in their annual reports. This item has been disclosed by 75 percent companies. The presentation of information by graphs, diagrams and pictures not only makes the annual report attractive but also easy to understand. On an average, 73 percent of the companies have used graphs and pictures. This technique of presentation has been used by 92 percent companies in 2014-15 in comparison to 54 percent in 1999-00. Highlights of the company are disclosed by more than half of the cos. It provides a bird's eye-view on the major items of information disclosed by company. Besides experts, this information is also helpful to the person who does not know how to analyze the profit and loss account and balance sheet of the company. The disclosure score is 71 percent for the year 2014-15 in comparison to 46 percent in 1999-00. It is a sign of improvement for disclosure of information by way of highlights. Corporate Mission, Vision \& Objective have been disclosed by 29 percent companies. There is no improvement in the percentage of companies disclosing it in 2014-15 over 1999-00. It shows the lack of vision of the management of the company in reporting this item.Chairman's report is a report which explains the general economic scenario, political \& economic scenario, industrial policy, impact of the policy information on production, sales, export information, profitability, dividend information, EPS, $\mathrm{R} \& \mathrm{D}$, future focus etc. the score of percentage of company's disclosing chairman's report/statement has increased to 42 percent in 2014-15 from 29 percent in 1999-00. However, on an average 35.5 percent of companies are disclosing this statement in their annual reports. The Emerging concepts in accounting like price level adjustment/ inflation accounting, value added statement, human resources accounting, balance sheet with tangible and intangible assets, brand values statement, enterprise value, economic value added statements, market value added statement etc. are disclosed only by 25 percent companies. It indicates poor disclosure score for this item over the period of study. Table 1.6 exhibits average number of items (i.e. average disclosure scores) for major items of information and their respective t-values.

Table 1.6

DISCLOSURE OF AVERAGE SCORES (NO. OF ITEMS) OF PRIVATE SECTOR COMPANIES

\begin{tabular}{|l|l|c|c|c|}
\hline \multirow{2}{*}{$\begin{array}{c}\text { Sr. } \\
\text { No. }\end{array}$} & \multicolumn{1}{|c|}{ Items of Information } & \multicolumn{2}{c|}{ Average Disclosure Score } & \multirow{2}{*}{ 't' values } \\
\cline { 3 - 4 } & & $1999-00$ & $2014-15$ & \\
\hline 1 & Contents & 9.67 & 17.30 & $5.14^{*}$ \\
\hline 2 & Director's Report & 24.42 & 37.00 & $5.95^{*}$ \\
\hline 3 & Chairman's Report & 2.88 & 8.30 & $7.60^{*}$ \\
\hline 4 & Corporate Governance & 1.71 & 13.33 & $10.33^{*}$ \\
\hline 5 & Mgt. Discussion \& Analysis & 3.25 & 11.42 & $12.30^{*}$ \\
\hline 6 & Share holder's Information & 10.75 & 27.33 & $9.47^{*}$ \\
\hline 7 & Information on Accountings \& Finance & 47.67 & 74.50 & $11.73^{*}$ \\
\hline 8 & Information on Personnel & 4.46 & 8.58 & $6.81^{*}$ \\
\hline 9 & Information on Marketing & 5.54 & 9.67 & $6.55^{*}$ \\
\hline 10 & Highlights & 3.17 & 7.96 & $4.51^{*}$ \\
\hline 11 & Mission \& Objectives & 0.29 & 0.29 & -- \\
\hline 12 & Presentation by Graphs \& Pictures & 4.46 & 8.58 & $4.31^{*}$ \\
\hline 13 & Social Responsibility & 1.42 & 3.71 & $5.31^{*}$ \\
\hline 14 & Emerging Concepts & 0.21 & 0.79 & $2.17^{*}$ \\
\hline
\end{tabular}

Source: Statistical values computed from Annual Reports of the Companies

Note: *- Significant at 0.05 level

Analysis of table reveals that the average disclosure score for major items of information has improved in 2014-15 over 1999-00. The average disclosure score is highest for information on accounting and finance in the year 1999-00 as well as 2014-15. It is stable for statement on mission and objectives. The average 
number of items disclosed in the emerging concepts has improved to 0.79 items in 2014-15 over 0.21 items in 1999-00. t- Statistics has been used to test whether there is significant difference in the mean scores of major items of information during pre-liberalization and post liberalization period. $t$-values at 0.05 level of significance suggest that out of 14 major items of information, the disclosure score is significant for 13 items. t-statistics could not be computed for mission. There is no sign of improvement in this item over the period of study.

On the basis of Company wise analysis of Disclosure Score and Analysis of Major items of information, it can be concluded that there is considerable improvement in the various items disclosed by Private Sector companies over the period of study. 